\title{
Crimes and Punishments, Part I: Mitot Beit Din as a Reflection of Rabbinic Jurisprudence
}

\author{
Devora Steinmetz \\ Jewish Theological Seminary
}

- or cases involving the commission of a capital offence, rabbinic sources 1 describe strict criminal procedure culminating, if the defendant is found guilty, in one of four modes of execution — arba mitot beit din. ${ }^{1}$ The power of Jewish courts to impose capital punishment and the precise nature of these modes of execution have long been the focus of intense scholarly discussion from a range of perspectives and within a range of academic disciplinesnot least, of course, because of the execution of Jesus by crucifixion, a mode of execution not listed among the four specified methods imposed by Jewish courts. $^{2}$

One approach to examining these sources takes as its starting point the thesis that the talmudic descriptions of execution ought not be taken either as evidence of what, in fact, took place or as evidence of what, in fact, took place or as prescriptions for what courts should (were they to regain the power to impose capital punishment) actually practise. The first element in this thesis stems largely from the fact that the system of criminal procedure and punishment in capital cases as described in the Talmud takes full shape only well after Jewish courts ceased to try capital cases and, thus, especially given some evidence to the contrary even within rabbinic sources themselves, we ought not assume that the Talmud is describing capital punishment as it actually took place. ${ }^{3}$ The second element in this thesis is based both on the ex-

${ }^{1}$ I would like to thank the following for reading and commenting on drafts of this study: Ruth Fagen, Richard Kalmin, David Shatz, Aharon Shemesh, and David Silber. I would also like to express my gratitude to the Shalom Hartman Institute in Jerusalem, and to its Director, David Hartman; much of the research for this study was accomplished during my stay there in 1999-2000 as a Fellow in the Institute for Advanced Studies.

2 For some approaches to critical questions related to mitot beit din, see, in addition to the sources that will be cited below, V. Aptowitzer, 'Observations of the Criminal Law of the Jews', $J Q R$ (N.S.) 15 (1924-25), 55-118; E. E. Urbach, 'Courts of Twenty-three and Laws of Judicial Execution' (in Hebrew), in haHalakha, Meqoroteha veHitpatchutah (Jerusalem, 1984), 47-53; and the review of the secondary literature and approaches in Y. Lorberbaum, Imago Dei: Rabbinic Literature, Maimonides and Nachmanides (in Hebrew), $\mathrm{PhD}$ dissertation, Hebrew University (Jerusalem, 1997), pp. 97-99 and notes 10-11. For one approach to crucifixion in relation to mitot beit din, see D. Halperin, 'Crucifixion, the Nahum Pesher, and the Rabbinic Penalty of Strangulation', JJS 32 (1981), 32-46, and the discussion in Lorberbaum, Imago Dei, 113-116. See also the discussions of 'hanging' in J. Baumgarten, 'Does TLH in the Temple Scroll Refer to Crucifixion?', JBL 91 (1972), 472-481; J. Heinemann, 'Early Halakha in the Palestinian Targum', JJS 24 (1974), 114-122; and Y. Yadin, Megilat HaMiqdash, vol. I (Jerusalem, 1977), pp. 285-289. See the censored aggada in bSan 43a on the execution of Jesus and the discussion by J. Z. Lauterbach, Rabbinic Essays (Cincinnati, 1951), pp. 490-500.

${ }^{3}$ See the reports of sereifa as actual immolation of the body in mSan 7:2, tSan 9:11, bSan 
ceptionally impractical nature of capital procedure as described in talmudic sources - especially the requirement that a warning be delivered to and accepted by the would-be criminal and the stringent rules for testimony and the examination of witnesses - and on the famous dispute as to whether a court ought ever impose capital punishment. ${ }^{4}$

All in all, we seem to have before us a system of criminal justice which is entirely theoretical, not just in fact, in that it was not practised as such, but in design, in that it seems not to have been conceived in order to be functional. If this is so, and I will take as my point of departure the position that it is, then rabbinic texts on criminal justice offer a distinctive opportunity to look at an ideal system of criminal law. Ideal, that is, not in the sense of 'perfect'for one of the critical points here is that such a system, in the real world, would be far from perfect (as Rabban Shim'on ben Gamaliel points out in his response to those who would apply the rules of criminal procedure to acquit all defendants in capital cases $)^{5}$ - but 'ideal' in the sense of reflecting fundamental ideas, rather than being bound to the realities of real criminals

$52 \mathrm{~b}$, and ySan 7:2/24b. Urbach, 'Courts of Twenty-three', assumes that there were simultaneous divergent practices in different local courts. Other take these reports to reflect actual practice and the rabbinic description of the arba mitot to represent a revision of judicial execution as actually practised. See H. Albeck, Seder Neziqin (Jerusalem and Tel Aviv, 1953), p. 448; Lorberbaum, Imago Dei, pp. 102-104. Rabbinic sources talk of capital trials ceasing to take place forty years before the destruction of the Temple; see ySan 1:1/18a and 7:2/24b, bSan 41a, bShab 15a.

4 The impractical nature of capital punishment is less extreme in the mishna than in other rabbinic texts. At least two requirements that are elaborated in other rabbinic texts would seem to make conviction impossible: the very strict requirements of hatra' $a$ (warning), including specification of the penalty by the person delivering the warning, explicit acceptance of the warning on the part of the one about to commit the crime, and the requirement that hatra' $a$ take place immediately preceding commission of the crime (see, for example, tSan 11:2-3, bSan 8b, 40b, $72 b, 81 b$, ySan 5:1/22c-d, and see the discussion below), and the requirement that witnesses see the actual crime in an indisputable manner (bMak $7 \mathrm{a}$ - to the point of needing to have verified, for example, that there was no fatal wound previously extant in the spot where a murder victim was stabbed; see also Mekhilta deRabbi Yishma'el, Kaspa 20 (ed. Horowitz-Rabin), p. 327, tSan 8:3, ySan 4:11/22b, bSan 36b). While hatra' $a$ and clear first-hand testimony are required by the mishna (mSan 4:5, 5:1), these requirements are not elaborated in the mishna in a way that would make them impossible to fulfil. See mMak 1:10 for a statement about the extreme rarity of judicial execution followed by R. Aqiva and R. Tarfon's statement, with which R. Shim'on ben Gamaliel takes issue, that no one would ever have been executed had they been on the Sanhedrin when dinei nefashot were still being implemented. See G. Blidstein, 'Capital Punishment-The Classic Jewish Discussion', Judaism 14 (1965), 159-171. Blidstein elegantly states the case for a theoretical rather than practical understanding of the rabbinic portrait of capital punishment: 'Indeed, Jewish law abolished capital punishment in fact not by denying its conceptual moral validity but rather by allowing it only this conceptual validity' (p. 164).

${ }^{5}$ See the preceding note on mMak 1:10. The famous 11th homily in Derashot HaRan emphasises the impossibility of maintaining social order through the exclusive means of judicial procedure as described in rabbinic sources. The Ran distinguishes between 'true justice' and social need, the latter requiring a more extensive power to punish and mandating a separate jurisdiction (that of the melekh, as opposed to that of shoftim). Whether the Ran sees the political leader as having only extra-judicial emergency powers or, rather, whether he envisions two distinct systems - each with its own goal and its own procedures and penalties - is debated. See, for example, G. Blidstein, 'On Political Structures-Four Medieval Comments', The Jewish Journal of Sociology 22 (1980), 47-58 and W. Z. Harvey, 'Liberal Democratic Themes in Nissim of Gerona', in I. Twersky and J. Harris, eds, Studies in Medieval Jewish History and Literature III (Cambridge, 2000), 197-211. See also the comments of the Rashba cited in Blidstein, p. 53 and nn. 22 and 23 . 
and the needs of real human societies.

But, while the rabbinic system of capital punishment is not bound by the demands of social need - in particular, by the need for punishment to serve as a deterrent ${ }^{6}$ - it is bound by and takes shape in reference to biblical sources about the penalty of death. ${ }^{7}$ Thus, while some elements of the rabbinic system of capital punishment seem to have been invented whole-cloth and others demonstrate a radical revision of the plain sense of the biblical material (and, no doubt, of actual practice in pre-rabbinic times ${ }^{8}$ ) we cannot see the rabbinic system as a creation ex nihilo. Bound as it is to its biblical sources, rabbinic tradition is limited by the constraints of these texts; while there is ample room for innovation and reinterpretation, biblical material must still be accommodated. Because of this, it might not be possible to see the system in its entirety as a mirror of rabbinic ideas, though I want to suggest that-if only as 'through a glass darkly' - the rabbinic system of capital punishment does reflect fundamental ideas of rabbinic Judaism.

One note before moving on. The passages on which the following argument

Rabbinic sources recognise the need for courts to react to criminal behaviour in ways not permitted under the basic rules of rabbinic criminal procedure and punishment. See, for example, tSan 12:6-7, mSan 9:5, and bSan $81 \mathrm{~b}$ on punishing a person who has committed a capital offence but who cannot be prosecuted because of the strict requirements of criminal procedure. See bSan 46a for a broad mandate for courts to punish acts that are not ordinarily punishable as violations of ('biblical') law. In addition, rabbinic sources recognise the power of the king/government to impose punishment—see tSan 9:10 (see Lorberbaum, Imago Dei, p. 125, n. 161), ySan 7:1/24b. Maimonides codifies both the power of the king to punish and the extra-systemic power of the courts to impose sanctions - see Hilkhot Melakhim 3:8-10, Hilkhot Sanhedrin 18:4-5 and 24:4-10, Hilkhot Rotzeach 2:4-5. Maimonides seems to distinguish between three types of power to punish outside of the rubric of standard dinei nefashot: the power of the king (which he can impose to protect his own honour or for the benefit of social order-the latter seems limited largely to responding to the crime of murder, though see Hilkhot Sanhedrin 18:6 (see the discussion of murder in the second part of this study, 'Crimes and Punishments, Part II: Noachide Law, Brother-Sister Intercourse, and the Case of Murder', forthcoming in JJS 54 (2003), and see the review of possible understandings of Maimonides' position in J. D. Bleich, 'Capital Punishment in the Noachide Code', Contemporary Halakhic Problems, vol. II, pp. 341-367, n. 11]); extrajudicial emergency powers of the court (hora'at sha $a$ - to be applied only when contemporary circumstances necessitate emergency action); regular powers of the court that extend beyond the rules of dinei nefashot to allow for broad-ranging penalties for law-breakers (so that courts may uphold adherance to the law among the general population).

${ }^{6}$ For some classic modern discussions of punishments and surveys of basic approaches to punishment and its goals, see H. L. A. Hart, Punishment and Responsibility: Essays in the Philosophy of Law (New York, 1968); H. Morris, On Guilt and Innocence: Essays in Legal Philosophy and Moral Psychology (Berkeley and Los Angeles, 1976); J. Murphy, Punishment and Rehabilitation, 3rd edn (Belmont, 1995); and M. Davis, 'Punishment Theory: Making Sense of What We Know About Punishment', NYSBA Law Studies 22 (1998), 3-10.

7 The idea that 'talmudic penology' reflects an ideal unconstrained by practical realities, but that it is constrained to some degree by biblical sources, is discussed by H. Cohn, 'The Penology of the Talmud', Israel Law Review 5 (1970), 53-74.

8 See, for example, Lorberbaum, Imago Dei, pp. 102-104 (on sereifa) and 134-137 (on seqila); Albeck, p. 448 (on sereifa) and 457 (on seqila). See M. Halbertal, Interpretive Revolutions in the Making (Hebrew) (Jerusalem, 1997), pp. 152-153. Whether sources such as Jubilees, Philo, and Josephus represent actual practice in the period of their authorship or in the recent past or, rather, their authors' understandings/interpretations of the biblical text is debatable. In any event, as Halbertal notes, these sources minimally show that the rabbinic descriptions of execution are interpretive choices among other possible interpretations of the biblical material. 
is based, both those relating directly to criminal procedure and punishment and others to which I refer in my interpretation of rabbinic conceptions of law, all appear in the Bavli, ${ }^{9}$ taken along with the mishna. ${ }^{10}$ Many of these passages have parallels in other rabbinic texts, some similar or identical to the passages in the Bavli and others highlighting the degree to which the Bavli can be seen as offering a distinctive perspective on a given point. It should be emphasised that I am making the claim neither that the argument offered here represents all rabbinic texts nor that it reflects a view unique to the Bavli. My sense is, rather, that much of the argument offered here is shared by a range of rabbinic texts, while the argument in full should best be seen as reflecting the rabbinic view of capital punishment and law as crystallised within the Bavli. My use of general terms such as 'rabbinic thought' should be understood in this qualified sense. The reader who is interested in analyzing the degree to which the Bavli is or is not representative of other rabbinic texts in relation to each of the subjects treated here as well as to the broader argument will find significant material in the notes relating to parallel sources, to ideas unique to the Bavli, and to the development of these and related ideas in later codes and commentaries.

\section{'Death That Has no Mark'}

Recently, two Israeli scholars have written about capital punishment from an approach similar to the one adopted here - that the modes of execution as described by rabbinic texts are shaped by a particular idea that was fundamental to rabbinic thought. ${ }^{11}$ The idea that I will be presenting as underlying these rabbinic sources, however, is different from the idea that these scholars present as shaping these sources about capital punishment. I will preface my own interpretation with a presentation of the basic thesis of these scholars and explain why I feel that an alternative understanding of the ideational underpinnings of these sources is called for.

Moshe Halbertal, in a book about the place of values in shaping rabbinic interpretation, suggests that the goal of the rabbinic revision and redesign of capital punishment was to minimise damage to the body of the executed

\footnotetext{
9 The one exception is the mandate to the government to execute by sword, which does not appear in the Bavli; see below at n. 60 and 'Crimes and Punishment, Part II', at n. 84.

10 See Sacha Stern, Jewish Identity in Early Rabbinic Writings (Leiden, 1994), pp. xxvi-xxvii, for the mishna as 'a work of the present' to the Amoraim; Stern comments: 'the Amoraim and Talmudic redactors treated Tannaitic sources, to some extent, as their own.' Looking at the Bavli along with the mishna does not, of course, suggest that the Bavli does not often present a different understanding than that reflected in the mishna. But, when the Bavli does not reinterpret or otherwise revise what the mishna says, it makes sense to look at the mishna as a part of the whole of the Bavli.

11 A third Israeli scholar, P. Segal, has also interpreted the rabbinic system of arba mitot as shaped by a fundamental idea. Segal sees each of these mitot as interpreted within rabbinic sources to simulate divinely imposed death, mita biydei shamayim, with the notion of atonement, such as that achieved through sacrifice, being central to execution. See 'Chiyuv bi Ydei Shamayim': Chiyuvei Mitot Beit Din veChiyuvei Mita leShamayim, $\mathrm{PhD}$ dissertation, Hebrew University (Jerusalem, 1986), and the abstract published as 'Postbiblical Jewish Criminal Law and Theology', Jewish Law Annual 9 (1991), 107-121.
} 
criminal - that is, to preserve his or her dignity as a person created in the divine image. ${ }^{12}$ Yair Lorberbaum develops a similar idea but roots this concern not in the ethical but in the mythic-theurgic domain, in a conception which sees the human being as an 'iconic extension' of God. ${ }^{13}$

Both Halbertal and Lorberbaum take as their paradigm the punishment of cheneq - execution by strangulation - a mode of death described in rabbinic sources as mita she'ein bah roshem - 'death that has no mark. ${ }^{14}$ Cheneq, as many have noted, is the one form of execution that has no precedent in biblical sources. ${ }^{15}$ As such, its invention and design are unconstrained by biblical descriptions of execution, and thus it is here that one might turn to see what execution might look like when designed solely as a reflection of rabbinic ideas. Halbertal and Lorberbaum extrapolate from their understanding of the motive behind the design of cheneq to discover what they assume to be the motive behind the rabbinic revision of the biblical modes of execution seqila and sereifa - stoning and burning.

The attraction of this approach is that it seeks to isolate a single primary motive, ${ }^{16}$ whether with ethical or mythic-theurgic foundations, to which can

12 Halbertal, Interpretive Revolutions, pp. 145-167. The notion that the goal of the design of some or all of the modes of execution was to minimise damage to the body was already suggested a century ago by N. Brüll, 'Miscellaneous Notes' (in Hebrew), Beit Talmud 4 (1885), 7-11, and again some years later by A. Büchler, but with a different rationale - to preserve the body intact for resurrection; see Lorberbaum, Imago Dei, pp. 97-98.

13 Lorberbaum, Imago Dei, pp. 96-158; for Lorberbaum's characterisation of his understanding of tzelem elohim, see especially p. 9. Halbertal's book is based on his dissertation, which preceded Lorberbaum's and to which Lorberbaum refers in his dissertation. It should be noted that both Halbertal and Lorberbaum focus on capital punishment as discussed in tanaitic sources, though each also cites selected passages from the Bavli and other rabbinic texts in developing his interpretation of the tanaitic material.

14 bSan 52b, Sifra on Lev. 20:10 (ed. Weiss, 92a), Mekhilta deRabbi Yishma'el, Neziqin 5, pp. 265-256, 267.

15 Hereg - execution by sword - also seems to be a rabbinic innovation as a form of judicial execution administered by the beit din. In the Torah, death by sword is mandated for the citizens of ir hanidachat (Deut. 13:16); this and murder are the only two cases for which rabbinic sources mandate hereg. A number of scholars have pointed out that ir hanidachat, in the Torah, seems less a case of judicial execution than a kind of war; compare the killing by sword that takes place after the sin of the Golden Calf (Ex. 32:27). See H. Albeck, Seder Neziqin, p. 453; M. Weinfeld, Deuteronomy and the Deuteronomic School (Oxford, 1972), pp. 91-100; Halbertal, Interpretive Revolutions, pp. 123-144; Lorberbaum, Imago Dei, p. 125, and 'Blood and the Image of GodThe Punishment of Beheading in Early Rabbinical Literature' (in Hebrew), Mechqerei Mishpat 15 (2000), 429-456, especially n. 34. Maimonides, Hilkhot Sanhedrin 14:1, includes only seqila and sereifa as explicit in the Torah; cheneq as the default mita is described as learned 'from Moses our master'; hereg for murder and ir hanidachat is simply stated as such. It has been argued that cheneq has its roots in the biblical mention of hanging (Deut. 21:22-23); see, especially, Halperin, 'Crucifixion', the discussions by Lorberbaum, Imago Dei, pp. 113-116, and A. Shemesh, 'Kama Mitot Nimseru leVeit Din veLama Himtzi'u Chazal et Mitat Cheneq', forthcoming in Mechqerei Mishpat.

16 Lorberbaum acknowledges the existence of other motives, as well; see, especially, 'Blood', in which the notion of tzelem elohim is seen by Lorberbaum as requiring decapitation of the murderer, despite the damage thus done to the body. In this case, though, Lorberbaum still maintains that tzelem elohim is the formative principle; how that concern is expressed in the case of punishing a murderer simply differs from the way it is usually expressed-by preserving the integrity of the body. Lorberbaum also acknowledges, for the Bavli but not for the Yerushalmi, a secondary concern with minimising pain; see Imago Dei, pp. 139-140. 
be attributed most details of the rabbinic system of capital punishment-the motive of minimizing damage to the body of the executed person. But I want to question the primacy of this motive in the design of the rabbinic arba mitot. In fact, I will question the notion that minimizing damage to the body per se - separate from a more general set of concerns about how we ought to treat human beings - is a goal of the rabbinic redesign of execution at all. Beyond that, I want to suggest a different way of looking at cheneq and how it relates to the other modes of execution within the system of arba mitot beit din. And, based on the view of cheneq that I will suggest, I want to offer a hypothesis about the introduction of cheneq as the default mode of judicial execution.

The source of the punishment of cheneq ${ }^{17}$ is presented several times in tannaitic sources; ${ }^{18}$ I will cite the version that appears in the Bavli:

Our Rabbis taught ... 'Die he shall be caused to die' (Lev 20:10) — by strangulation. You say by strangulation - or perhaps it should be by one of the [forms of] death stated in the Torah?

Say - wherever it says 'death' unspecified in the Torah you may not draw it to make it more severe, rather to make it more lenient - the words of Rabbi Yoshiya. ${ }^{19}$

Rabbi Yonatan says: Not because it is more lenient, rather-any 'death' stated unspecified in the Torah is none other than strangulation. ${ }^{20}$

17 As noted in n. 19, below, it is not entirely clear whether this is presented as the source of the existence of the mita of cheneq or simply of the idea that cheneq is the mandated punishment in a given case or set of cases.

18 See bSan 52b, Sifra on Lev. 20:10 (92a), Mekhilta deRabbi Yishma'el, Neziqin 5, pp. 265 256, 267, and also ySan 7:1/24b and 7:4/24b-c (the Yerushalmi passages do not include the entire range of opinions).

19 Rabbi Yoshiya is working with the assumption that cheneq is the most lenient form of execution, an assumption debated by R. Shimon in mSan 7:1. In addition, as the Bavli points out, his position only makes sense if one already has the notion that there is a fourth form of execution in addition to seqila, sereifa, and hereg. See n. 55, below. In other words, Rabbi Yoshiya is not explaining the source of the existence of this fourth mita - according to the Bavli, there must be a pre-existing tradition that there are four mitot. Maximally, Rabbi Yoshiya is identifying what that fourth mita is - it must be something more lenient than the other three, and the most lenient form of death is death by strangulation. Minimally, he is working with the assumption not only that there is a fourth mita, but that this fourth mita is cheneq and that, once we know that cheneq exists, we can infer that cheneq is the default mode of execution to be administered when the Torah does not specify a different mita. Rabbi, on the other hand, seems to be deriving the notion of strangulation from the verse cited, basing this derivation on the symmetry between divinely imposed and judicially imposed death. The Bavli, though, appears to see Rabbi not as deriving the idea of strangulation but as simply identifying what mita the verse is referring to; the Bavli asks, according to Rabbi, why we might not see the verse as referring to sereifa, since, as rabbinically understood, this form of execution, too, leaves no mark on the body of the criminal. The notion of sereifa as leaving no mark on the body, though, is clearly derivative - it is not the essential definition nor the essential characteristic of sereifa in rabbinic sources, as it is of cheneq (see n. 35, below, on later interpretations of the purpose of the sudar in sereifa that take the notion of not leaving a mark on the body in sereifa as formative in regard to at least this detail of sereifa). In the parallels in Sifra and Mekhilta (see preceding note), we have the term mikan amru-implying that these sources see Rabbi's teaching as the source of cheneq as a mode of execution. See Lorberbaum, Imago Dei, pp. 118-119, for a different understanding of the implication of mikan amru in these sources.

20 Rabbi Yonatan's reasoning is difficult; according to bSan 53a he and Rabbi are of the same opinion, and Rabbi is merely elaborating on Rabbi Yonatan's reasoning. In ySan 7:4/24b-c, R. Yonatan is cited as disagreeing with R. Yoshiya, but Rabbi's comment is not cited. 
Rabbi says: 'Death' by the hand of heaven is stated, and 'death' by the hand of a human being is stated - just as 'death' that is stated by the hand of heaven is death that has no mark (mita she'ein bah roshem), so too 'death' that is stated by the hand of a human being is death that has no mark.

Lorberbaum takes Rabbi's position to be emphasizing two inter-related points: '(a) Death by the hand of a human being may not leave a mark on the body of the defendant. (b) Judicial execution must imitate death by the hand of heaven: just as there is no mark in the latter, so too, in the former [plural] - it is forbidden that they leave a mark. ${ }^{21}$ For Lorberbaum, then, not leaving a mark on the body is in and of itself desirable; thus he sees point (a) as distinct from point (b) and, in fact, gives it pride of place in his analysis of Rabbi's position. Further, reading Rabbi's statement as referring to mitot beit din in general, not just to cheneq, Lorberbaum extends his understanding of ein bah roshem as a desideratum to all forms of judicial execution. ${ }^{22}$ And, beyond that, both Halbertal and Lorberbaum see this as the formative motive behind both the creation of cheneq and the redesign of the biblical punishments of seqila and sereifa.

It seems to me that there are at least three significant problems with this argument. First, ein bah roshem is not stated as a general principle to be applied to all forms of judicial execution; ${ }^{23}$ it is stated only in relation to cheneq. In fact, it seems to me that it is not stated as a substantive goal at all, even in the context of cheneq. That is, Rabbi is not asserting that, a priori, we want to find a mode of execution that leaves no mark; he is asserting that, when the Torah mandates simply 'death', we ought to impose death - we ought to take the person's life in a way that most closely approximates the way God takes life. This is a design-principle limited to cheneq, and it does not have as a goal leaving no mark; the objective, given the mandate to impose 'death', is to approximate death by God's hand, ${ }^{24}$ and we do this by imposing a form of execution that leaves no mark. I will return to this idea below, when we move on to an alternate understanding of the rabbinic innovation of cheneq.

Second, Halbertal and Lorberbaum move easily from ein bah roshem to minimizing damage to the body. But, if we take ein bah roshem as a charac-

${ }^{21}$ Lorberbaum, Imago Dei, p. 118. See n. 51, below, for a discussion of what 'death ... by the hand of heaven' Rabbi might be referring to; the accompanying text discusses how we might understand this form of death and its simulation by cheneq.

${ }^{22}$ Lorberbaum reads Rabbi's formulation as stating a general principle and cites the version of the argument in Mekhilta deRabbi Yishma el, Neziqin 5, p. 266, in support of this reading; see n. 19, above. Halbertal sees Rabbi's formulation as referring specifically to cheneq, but understands this to reflect a general desideratum that influenced the redesign of seqila and sereifa as well (Interpretive Revolutions, pp. 155-156). Halbertal sees R. Yoshiya as agreeing, in principle, with Rabbi (whom he takes to be in agreement with R. Yonatan) - 'lenient' here being understood as minimising damage to the body.

${ }^{23}$ Lorberbaum's conviction of the general nature of this principle leads him to raise this as the basis for analysis of what, based on this principle, is the outrageous deviance of the penalty of hereg - a form of execution imposed by rabbinic sources which does, indeed, leave a significant mark on the body of the condemned; see 'Blood'.

24 P. Segal ('Postbiblical Jewish Criminal Law') explains Rabbi's argument as deducing cheneq 'from natural death at the hand of heaven without a mark', while Lorberbaum rejects the notion that mita biydei shamayim here refers to natural death (Imago Dei, pp. 118-119). 
teristic of divinely imposed death that cheneq is designed (or chosen) to approximate, which is what the tannaitic sources plainly say, then this is not a spectrum characteristic. ${ }^{25}$ In other words, we cannot move from the notion that, in imposing cheneq, we are to execute in a way that leaves no mark to the notion that we must seek, when in fact we are destroying the body, as in seqila for example, to minimise the mark left on the body. If the idea is to choose or design a form of humanly imposed death that simulates divinely imposed death by leaving no visible mark, then we either succeed - by depriving the condemned person of life in a way that leaves no physical trace of that process, which is what we are asked to do in cheneq - or we do not.

Third, while Halbertal and Lorberbaum explain many details of the rabbinic refashioning of seqila and sereifa as designed to minimise the mark left on the body, for most of these elements there are at least equally plausible alternate explanations. And, even when minimizing damage to the body does appear to be the goal, that can be understood best not as a distinct principle concerning the body, but rather as one application of a wider principle that requires one to treat people with respect and consideration.

For example, Halbertal and Lorberbaum see the radical refashioning of sereifa from immolation of the body to an internal burning of the person as motivated by the desire to leave the body intact. ${ }^{26}$ But one could offer several other explanations for this form of sereifa - the most obvious, of course, being the desire to minimise the suffering of the condemned by hastening death, ${ }^{27}$ a motive explicitly mentioned in the Bavli in relation to both sereifa and seqila and given by the Bavli as the reason that internal burning is chosen over external burning as the way in which sereifa ought to be done. ${ }^{28}$

25 This is different in kind from, say, the goal of minimising pain, about which one could say that the ideal is a painless death but that, if this is impossible, we seek the closest thing - the least painful death. Halbertal and Lorberbaum understand ein bo roshem in this way, as the ideal realisation of the goal of minimising damage to the body, a goal that can be realised to a greater or to a lesser degree.

26 See Lorberbaum, Imago Dei, pp. 111-112, and Halbertal, Interpretive Revolutions, pp. 147-

27 Lorberbaum (Imago Dei, p. 111) denies, as does Urbach ('Courts of Twenty-Three'), that this form of sereifa was understood to be a quicker form of death; the Bavli, however, clearly believes that this is so-see bSan 52a and n. 32, below. An interesting parallel to the contrast in immediacy between internal and external burning, especially given one of the Sifra's descriptions of the death of Nadav and Avihu (Milu'im 23 on Lev. 10:2 [45a] and 34 on Lev. 10:2 [45b]), found also in bSan 52a- 'two threads of fire came out from inside the Holy of Holies and were divided into four; two went into the nose of one and two into the nose of the other ...' - is the description by Helen Prejean of the problematic nature of electrocution as currently implemented in Dead Man Walking: An Eyewitness Account of the Death Penalty in the United States (New York, 1994), pp. 18-20. Prejean argues that, while the goal of electrocution is to achieve immediate and therefore painless or near-painless death, the fact that the electrical charge is administered externally makes death take several minutes. In the description of the burning of Nadav and Avihu, in contrast, the divinely sent fire is delivered directly to the interior of the bodies of the men.

28 Sereifa-bSan 52a (see preceding note); seqila-bSan 45a, discussing the question of whether a woman should be stoned naked to minimise discomfort to the body or clothed to minimise humiliation, and also, on the same page, explaining the law that the condemned is cast from higher than the minimum height that can be fatal because of the principle of "choosing a fine death'. 
Another possible explanation, based on the attempt in the Bavli $^{29}$ to derive this mode of sereifa from a gezeira shava between the penalty of sereifa and the use of this word in reference to the miraculous death of either Aharon's sons or Qorach's congregation, is that we have in sereifa, as well as in cheneq, an attempt to imitate divinely imposed death. ${ }^{30}$ The sugya in the Bavli, however, subordinates this derivation to the goal of minimizing suffering; it sees these gezeirot shavot as simply letting us know that internal burning qualifies as sereifa within biblical discourse. ${ }^{31}$ Once this is so, according to the conclusion of the sugya, we need simply apply Rav Nachman's dictum 've'ahavta lerei'akha kamokha'-beror lo mita yafa ('you shall love your neighbour as yourself' - choose for him a fine death), and our choice of how we must fulfil the biblical requirement of sereifa becomes clear. ${ }^{32}$

29 bSan 52a; see Sifra Milu'im 23 on Lev. 10:2 [45a], 27 on Lev. 10:5 [45a], 34 on Lev. 10:2 [45b], and 41 on Lev. 10:6 [46a] and parallels discussed in Lorberbaum, Imago Dei, pp. 106-110. These sources include conflicting opinions about the nature of these miraculous deaths: (1) the bodies were burnt but the clothes were not; (2) the neshama was burnt but the body remained intact. It is based on the second conception that the analogy to sereifa as internal burning is drawn. Lorberbaum sees this second tradition as earlier and more authentic. The inconsistency in the Sifra is already noted by Tosafot on bSan 52a, s.v. hahi sereifa mamash havai. It is discussed by Lorberbaum, Imago Dei, p. 108 and n. 65. See also A. Goldberg, 'haDrashot haKfulot be Mekhilta deMilu'im', Sinai 89 (1981), 115-118.

30 This would be quite different than for cheneq, though, since in cheneq we seem to be approximating natural death while in sereifa we seem to be approximating miraculous death. See Lev. 9:24 and Num. 16:35, where the fire is of divine origin - while the way it kills might, nevertheless, be understood simply as natural immolation, it is not too great a step to move from miraculous fire of divine origin burning naturally to this special fire killing in a miraculous kind of way. See also the divine fire in Num. 11:1-3 and the 'fiery' snakes in Num. 21:6-9.

Alternatively, we might see the description of the deaths of Nadav and Avihu and of Qorach's congregation as neshama nisrefet veguf qayam as a different form of 'natural' death-perhaps more similar to death that results from illness/fever. (I use 'natural' here only in the sense of how people die absent an externally imposed physical cause; it is, in fact, an unfortunate choice of words in that 'natural' and biydei shamayim represent radically different conceptions of how death is caused.) See Lorberbaum, Imago Dei, p. 109, n. 71, and Aptowitzer, 'Observations', p. 62, n. 27, who cite the description of the death of a sick person in bAvoda Zara 20b: 'the Angel of Death ..., at the time that a sick person departs, stands at his head, and his sword is drawn in his hand, and a drop of gall hangs from it; when the sick person sees him, he is shaken and opens his mouth, and he throws it into his mouth - from it he dies'. See also the description of illness as fire from heaven in bNed 41a.

Lorberbaum rejects the notion that, in rabbinic sources (as opposed to in Syriac Barukh 63:8 see J. Charlesworth, The Old Testament Pseudepigrapha, I (Garden City, 1983), p. 643), internal burning is described to emphasise the miraculous nature of the deaths of Nadav and Avihu and others. For Lorberbaum, the rabbinic sources emphasise the merciful nature of these deaths, in that God preserves the bodies of the victims. Lorberbaum dismisses as erroneous Sifra Milu'im 27, which sees God's mercy in preserving the clothes of Nadav and Avihu while their bodies were burnt, since Lorberbaum assumes that preservation of dignity is coterminous with preservation of the body (see, though, n. 28, above and the discussion below-clearly, rabbinic sources recognise other ways than preservation of the body that dignity can be preserved, including being clothed). Segal, as noted above, n. 11, sees the description of sereifa as well as of all the other mitot as reflecting divinely imposed deaths; see Chiyuv bi Ydei Shamayim and 'Postbiblical Jewish Criminal Law'.

31 As noted below in the context of Rabbi's derivation of cheneq, it is difficult to know whether one should take details of an argument like this to be merely formal elements or whether one should see them as disclosing fundamental conceptual elements of the argument; see n. 67.

32 Halbertal, Intepretive Revolutions, pp. 147-149, discusses this sugya and notes that, accord- 
At least two other possible explanations for the redesign of both seqila and sereifa ought to be mentioned. One is the desire to minimise violation of the condemned person's dignity. This goal is cited explicitly in the Bavli's discussion of whether women ought to be stoned naked. The presumption is that being naked, on the one hand, will hasten death and, on the other hand, is humiliating for the condemned person. Thus, within the broad rubric of 've'ahavta lerei 'akha kamokha', we have, in this case, competing goods: hastening death versus preserving dignity. ${ }^{33}$ The crucial point is that preserving dignity is a consideration that falls within the imperative of 've'ahavta lerei 'akha kamokha' - beror lo mita yafa along with several other considerations, including minimizing pain by hastening death. Further, and importantly for our discussion, when minimizing damage to the body is mentioned as a goal, ${ }^{34}$ it is probably best explained as a sub-category of preserving the person's dignity - that is, again, as mandated by the broad imperative of 've'ahavta lerei 'akha kamokha', not as a principle unto itself. ${ }^{35}$ And so, even if

ing to its conclusion, the case of Qorach's congregation simply extends the semantic range of sereifa but that it is the principle of beror lo mita yafa that determines the choice of how the biblical requirement of sereifa will be interpreted. Halbertal, though, identifies the determining value here as avoidance of damage to the body, not as hastening death/minimising pain.

33 bSan 45a; see n. 28, above.

${ }^{34}$ Nivul is mentioned, besides in the difficult mishna about hereg (mSan 7:3), in the Bavli's discussion of seqila. If we raise the stoning platform above the minimum height in order to help ensure a quick death (the clear implication, even according to Lorberbaum, of beror lo mita yafa here), then why do we not make it even higher than the mandated two stories? The gemara responds: because the condemned person would become disgraced/disgusting. While nivul here is a function of damage to the body, we ought not identify the two notions. See bArakhin $7 \mathrm{~b}$ : a pregnant woman about to be executed is first struck across the abdomen so that she not be disgraced in the course of execution by signs of labour. The disgrace here is refered to as nivul, yet this is not a case of damage to the woman's body. The most narrowly we can define nivul, then, is as disgrace having to do with something physically unsightly, but not necessarily with disfigurement. More broadly, nivul could refer to practice that is disgraceful in a variety of wayssee, for example, Tosafot on bSan 52b, s.v. Rabi Yehuda omer nivul hu ze, commenting on mSan 7:3: R. Yehuda says that the notion of decapitating in the way the (non-Jewish) government does is nivul because it violates uvechuqoteihem lo teleikhu - 'and by their laws you shall not go' (Lev. 18:3).

${ }^{35}$ Lorberbaum (Imago Dei, p. 112 and n. 87) assumes that the reason for the sudar raka in cheneq and seqila is to prevent leaving a mark on the person's body; see Rashi on bSan 52a, s.v. qasha letokh haraka and Yad Rama on mitzvat hanisrafin (p. 100). Lorberbaum rejects the explanation in ySan 7:2/24b for the sudar raka in sereifa - that the condemned not die of strangulation by the sudar qasha; Lorberbaum feels that the explanation for the two sudarim should be the same for sereifa and for cheneq, and the Yerushalmi's explanation obviously could not apply to cheneq. It should be noted, though, that Rashi gives a similar explanation as that which he gives for the sudar for another detail of sereifa - mashqi in otot bezevel. Rashi (bSan 52a, s.v. mashqi in oto) says that this is in order to immobilise the condemned so that the petila not fall on the outside of the body (though whether Rashi sees the mishna as concerned to avoid nivul or pain is unclear here - in any event, it should be noted that the Bavli already sees sereifa as leaving no mark - bSan 52b - see above, n. 19-and it may be because of this, rather than because of a general concern, that Rashi interprets one of more of the details of sereifa as designed to avoid disfigurement). This explanation, in fact, cannot be used to account for the same procedure in cheneq, since there is no petila that might fall on his body should he move during the process of execution. An alternative explanation for mashqi in that could apply to both sereifa and cheneq, suggested by the Yad Rama, p. 100, is to preserve the dignity of the condemned should he soil himself during the execution. (See Prejean, Dead Man Walking, p. 92 for a contemporary mea- 
one consideration in the redesign of sereifa and seqila is to minimise damage to the body - and, in the case of seqila, the Bavli explicitly offers this as an explanation for the relatively low height of the 'stoning' platform - it seems most reasonable to see this as one of several ways that we seek to design a mita yafa ${ }^{36}$ rather than as a goal in-and-of itself and a predominant one at that.

Another alternate explanation is that we have, in the redesign of the biblical punishments of seqila and sereifa, a radical institutionalizing as judicial execution of forms of destruction of the person that, apparently, have their roots in spontaneous expressions of communal outrage ${ }^{37}$ against those who violate central norms of the community. Whereas the Bible, of course, mandates these acts as punishments ${ }^{38}$ to be imposed within official contexts and following upon particular procedures of accusation, proof, and condemnation, ${ }^{39}$ rabbinic sources go well beyond this in their systematisation of dinei nefashot. Many elements of the rabbinic redesign of the biblical punishments of seqila and sereifa, similarly, can be seen as ways of handing over execution to the courts and minimizing the participation of the larger community. ${ }^{40}$ The rab-

sure to address this concern and see mMak 3:14 on the possibility that this might occur during malqot.) One could, perhaps, explain the sudar raka in both sereifa and cheneq as designed to minimise pain.

36 Alternatively, we could see the concern to avoid nivul as falling under the general rubric of kevod habriyot. In either event, damage to the body is only one form of nivul, and avoidance of nivul is only one way we adhere to a broader imperative.

37 Threats or acts of spontaneous seqila or sereifa occur in Ex. 17:4, Num. 14:10, I Sam. 30:6, I Kings 12:18 and in Judges 12:1, 14:15, 15:6, respectively. Akhan (and his family and property) are both stoned and burnt, then left under a pile of stones, in Josh. 7:25-26. See bSan 44a on this combination of acts. For additional, non-biblical sources, see Albeck, Seder Neziqin, p. 457.

38 Seqila is specified in the Bible for crimes having to do with idolatry, necromancy, and blasphemy (Lev. 20:2, if this is understood to refer to an idolatrous practice, 20:27, 24:14, Deut. 13:11, 17:5); violation of Shabbat (Num. 15:36); the rebellious son (Deut. 21:12); and two specific sexual offences (Deut. 22:21, 24); plus the ox that gores (Ex. 21:28). Sereifa is specified for two sexual offences (Lev. 20:14, 21:9). See also Gen. 38:24 (and see Shemesh, 'Kama Mitot', for how this passage was incorporated into the criminal law of Jubilees). Many scholars believe that seqila is assumed by the Bible as well as by its early interpreters to be the standard form of execution, except for special cases (limited, perhaps, to particular sexual violations?) which are punishable by sereifa. See, for example, Albeck, Seder Neziqin, p. 457; Aptowitzer, 'Observations'; Shemesh, 'Kama Mitot'. Nevertheless, most of the crimes for which seqila is explicitly specified constitute major offences against communal norms in response to which the community is asked to participate in destroying the criminal: crimes against God (idolatry, necromancy, blasphemy), sexual offences, violation of Shabbat. See the discussion of major sins in bSan 74a. For murder, see the discussion in 'Crimes and Punishments, Part II'. At least one of the two sexual offences for which seqila is mandated is described as a violation of the violator's father (Deut. 22:13-21); compare the case of the rebellious son (Deut. 21:18-21) - note the involvement of both father and mother in both of these cases. Perhaps the rabbinic list of crimes punishable by seqila (mSan 7:4) can be somewhat accounted for based on these categories; see also n. 48, below.

39 Some biblical passages describe judicial (or quasi-judicial) procedures quite extensively, while others simply state the penalty. There is also a range of people designated as in charge of the proceedings (for example, ziqnei ha ${ }^{\prime}$ ir in Deut. 21:20 and 22:15 and also in Deut. 19:12 as opposed to ha eida in Num. 35:24-25) as well as a range of locations for the execution (for example, sha'ar meqomo in Deut. 21:19; petach beit aviha in Deut. 22:21; michutz lamachane in Lev. 24:14 see mSan 6:1, tSan 10:10, ySan 6:1/23b, yKet 4:5/28c-d, bSan 42b, bKet 45b) - see Halbertal, Interpretive Revolutions, p. 146.

${ }^{40}$ H. Cohn, 'The Penology of the Talmud', emphasises the shift from public act to exercise of 
binic forms of these punishments, first, limit the number of people included in the execution; gone, in practice, is the notion of 'the entire community' stoning the condemned person, though that possibility is still preserved in theory. ${ }^{41}$ Second, the spectacular nature of these punishments is minimised; along with immediate (or, at least, less-prolonged) death, there is less attraction for spectators to come and watch the process of dying. ${ }^{42}$ Third, as Halbertal points out, the destruction and elimination of the criminal effected by biblical seqila and sereifa seems designed to eliminate the person as the embodiment of evil from the community that has been marred by the criminal act. ${ }^{43}$ The judicial notion, while possibly still maintaining the idea that pun-

judicial duty as accounting for elements of the redesign of seqila, along with considerations of minimizing pain and mutilation of the body.

41 See the biblical passages in $\mathrm{nn} .37$ and 38, above, for the participatory nature of seqila, in particular. See Halbertal, Interpretive Revolutions, pp. 149-153, on the shift in rabbinic sources away from community participation in seqila; Halbertal attributes this shift to the desire to minimise damage to the condemned criminal's body. Note Halbertal's citation (p. 152) of Philo, Life of Moses II, 202, who sees the biblical punishment of seqila as expressly designed to allow community participation in the response to the outrageous crime that has been committed (referring to the blasphemer in Lev. 24:14). Rabbinic sources retain the theoretical possibility of communal participation in seqila, in the event that the condemned is killed neither by being pushed off the platform by the first witness nor by having the stone cast down by the second witness; see mSan 6:4. The Bavli denies that the condemned ever survived to the point of the general community participating in the process of stoning; see bSan $45 \mathrm{~b}$. While retaining the possibility of community participation in seqila may simply be necessary to fulfil the requirement of the biblical sources (see mSan 6:4, citing Deut. 17:7), it is also possible that rabbinic sources actively retain the conception of seqila-punishable crimes as violations of communal norms the penalty for which ought to express - at least as constructed, if not necessarily as implemented — communal outrage. Note that it is only in the case of seqila that the mishna makes it clear that it is the witnesses who perform the execution, though Maimonides takes this to be the case for all modes of execution (Hilkhot Sanhedrin 13:1), as may be implied by the challenge posed by the citation of mMak 1:10 in bSan $45 \mathrm{~b}$ (depending on whether the gemara understands mMak 1:10 as speaking specifically about the case of murder or as referring to any capital offence-if the former, then the gemara seems to assume that even in hereg the witnesses perform the execution; if the latter, then the gemara might not be assuming that the witnesses perform the execution in any case other than seqila, and the challenge is posed in relation to seqila, as one of the cases included in the mishna's general law). Again, the mishna's specification of the participation of the witnesses in seqila could be seen simply as a constraint of the biblical sources, or we might see this detail as integral to the rabbinic conception of seqila and the crimes which it punishes. If we see the notion of communal participation as integral still to the rabbinic conception of seqila, there might be greater reason to try to account for the rabbinic list of seqila-punishable crimes in the way mentioned in $\mathrm{n}$. 38 , above. In tSan 9:6, R. Shimon describes the casting of the stone as a required component of the procedure and as simply mandated by the biblical prescription - kedei leqayeim bo mitzvat seqila - just as the very minimal hanging of the executed criminal is performed kedei leqayem bo mitzvat teliya. In contrast, the Bavli asserts that pushing the person off the platform qualifies as a fulfilment of the biblical requirement and that casting a stone is not necessary; see bSan 45a. The Tosefta mentions neither the possibility of the community participating nor the specification that the execution be performed by the witnesses. While both the mishna and the Tosefta, then, have the casting of the person as well as (the possibility of) throwing a stone upon the condemned, only the mishna explains the course of events in reference to the participation of both witnesses and of the community.

42 See M. Foucault, Discipline and Punish: The Birth of the Prison (New York, 1995), especially pp. 32-69, for an interpretation of execution as a spectacle. Biblical sources emphasise the public awareness of execution, if not its spectacular nature, as a deterrent; see especially Deut. 13:10-12 and 17:7.

${ }^{43}$ See Halbertal, Interpretive Revolutions, pp. 145-146 (seqila) and 152 (sereifa). Note the 
ishing the criminal has good effect on the nature and integrity of the community, ${ }^{44}$ seems to focus, rather, on the person who has violated the law and on what the court must impose on that person according to the requirement of the law. Thus, the need to eliminate the person bodily, as the embodiment of sin, loses its meaning, and the focus in designing execution shifts to doing justice to the person who has violated the law. It is noteworthy in this regard that, while seqila and sereifa in their plain sense can be done from afar, and may perhaps even incorporate the notion of distancing the criminal from the community, ${ }^{45}$ as rabbinically redesigned forms of execution they, like hereg and cheneq, require direct contact between the executioners and the condemned person. ${ }^{46}$

If, in fact, there are a variety of plausible explanations for elements of the redesign of seqila and sereifa other than the goal of minimizing damage to

burying of Akhan, his family and his possessions under a mound of stones in Josh. 7:25-26; the swallowing up of Qorach, Datan, and Aviram and their families and possessions in Num. 16:32, followed by the immolation of Qorach's congregation in 16:35; and the burning of ir hanidachat and its possessions in Deut. 13:17.

44 Note the frequent mention of uvi'arta hara ' miqirbekha in Deut. in the context of execution (13:6, 17:7, 17:12, 19:19, 21:21, 22:21, 22:22 (miyisra'eil), 22:24, 24:7). The execution of the criminal, in these passages, serves in some way to set the community right, beyond ridding the community of the danger posed by the criminal or by deterring similar criminal activity on the part of others. This may be through removing the criminal as the embodiment of evil-doing from the community (see previous note), by reaffirming the community's values through the condemnation expressed through punishment of the violator, or by restoring the balance of the community by doing harm to the wrong-doer. For a concise summary of conceptions of punishment that goes beyond the standard categories of retribution, rehabilitation, and deterrence, see Davis, 'Punishment Theory'.

45 Note the injunction to bring the person about to be stoned 'outside of the camp' in both the stories of the blasphemer (Lev. 24:14) and the wood-gatherer (Num. 15:35). The former passage is cited in mSan 6:1 as the source of the location of the stoning platform outside of the court. See the discussion of this passage in bSan $42 \mathrm{~b}$; among other ideas, the gemara suggests that the court wants to distance itself from the execution - 'so that the court not appear to be murderers' - a notion quite different from the distancing of the condemned criminal from the society whose norms he has violated. The Bavli also introduces a baraita which says that the criminal is executed outside of the 'three camps' (=outside of the city; see Rashi, s.v. chutz leshalosh machanot, and Tosafot, s.v. beit hasqila hayta chutz leshalosh machanot) and compares this to the sacrifice brought when the entire community sins. This suggests that one of the functions of execution is to re-stabilise the community, perhaps along the lines suggested in the preceding note.

46 This means, among other things, that the court takes full responsibility for the execution as part of its judicial responsibility (notwithstanding the distancing from the court mentioned in the preceding note) and also that the responsibility for the condemned person's death is not shrouded behind the anonymity of a group killing. In contrast, stoning by the community as described in the Torah, while it involves the entire community in the destruction of the criminal, also leaves no individual responsible for the actual death of the condemned person. The latter characteristic of stoning can be found in modern times in the practice of execution by firing squad or in methods of execution that devise ways to make it impossible to know who has actually caused the death. As noted above, n. 41, it is not entirely clear in rabbinic sources who performs the execution, except in the case of seqila, where the witnesses do (for who performs hereg in the case of the execution of a murderer, see the discussion in 'Crimes and Punishments, Part II'). Are we to see the witnesses as representatives of the community, as agents of the court, as representing the interface between the community and the court — or, perhaps, as a representation of the criminal's self-condemnation through choosing to act as he has done, since it is the witnesses who attest to the criminal's commission of the act pursuant to his acceptance of the hatra'a? See nn. 76 and 77 , below. 
the body, and if, as I have argued, ein bah roshem does not suggest a general principle that one must minimise damage to the body when performing executions, then we have to look elsewhere to try to account for the rabbinic innovation of cheneq. How did cheneq get introduced as a form of mitat beit din, ${ }^{47}$ and why is it the form designated as the default mita, in cases where the Torah does not designate a specific form of execution? ? $^{48}$

Of course, it is possible that cheneq represents the adoption or adaptation of a form of execution common in the surrounding cultures during the rabbinic period. ${ }^{49}$ And it is also possible that the idea of execution by cheneq was introduced simply because this mode of execution was seen as less painful or more immediate than the other, ancient options - the biblical sanctions of seqila and sereifa - even in their redesigned rabbinic forms. ${ }^{50}$ But, even if the idea of cheneq has its historical source in surrounding practice or in a general reform of criminal punishment, we can, and should, try to understand its meaning within the system of criminal procedure and punishment described and discussed in rabbinic texts. Let us return to how the choice of cheneq is explained in these texts and, then, to a look at the place of cheneq within arba mitot beit din.

\section{Cheneq and its Place within Arba Mitot Beit Din}

Cheneq, according to Rabbi, is indicated by the Torah's unqualified use of the word 'yumat' - 'he shall be caused to die' (Lev. 20:10); since forms of the word mita are used to connote 'death by the hand of heaven', we must, when the Torah uses this word in a (presumably) judicial context, impose a form of death similar to divinely imposed death: mita she'ein bah roshem. The simplest understanding of the notion that 'death by the hand of heaven' is mita she'ein bah roshem is this: 'death by the hand of heaven' refers, simply, to the way people die, to what we might call a natural death. ${ }^{51}$ The way people die, when

47 See A. Shemesh, 'Kama Mitot', for a new attempt to account for the introduction of cheneq to mitot beit din.

48 Though designated as the default mode of execution, cheneq is not the mita mandated in rabbinic texts for every crime for which the Torah does not specify the mode of execution. Several crimes are assigned in mSan 7:4 to seqila, some, but not all, of which are linked in the Torah to the words damav bo, which are taken in rabbinic sources to indicate seqila (see Sifra on Lev. 20:9, 11, 13, 16 [92a-b] and, especially, 27 [93b], Mekhilta deRabbi Yishma el, Neziqin, p. 268, Mekhilta deRashbi, p. 173, bSan 66a; see Shemesh, 'Kama Mitot'). In addition, with respect to a number of crimes there are debates within rabbinic sources about which mode of execution is to be imposed.

49 See Halperin, 'Crucifixion', and related sources cited in n. 15, above.

50 What it means for cheneq to be qal is unclear-see Shemesh, 'Kama Mitot', n. 9. Halbertal, Interpretive Revolutions, p. 155, sees this as a function of cheneq leaving the body intact. According to both positions in the mishna (mSan 7:1), cheneq is more qal than seqila and sereifa. While there is an opinion that cheneq is less qal than hereg, hereg seems to be limited to a very small number of particular crimes - thus, it is still possible to suggest that cheneq was introduced as a less painful, broadly implemented alternative to seqila and sereifa.

51 What precisely Rabbi is referring to by the phrase mita biydei shamayim is unclear. Rashi (bSan 52b, s.v. ne'emar mita biydei shamayim) cites the causative form vayamet in Gen. 38:10; Onan, like Er in Gen. 38:7, is 'caused to die' by God in response to God's judgement that his action was evil. This source is particularly apt since the death is in response to an evil act and since the form of the verb here has death being caused, rather than the person simply dying. 
there is no obvious cause of death such as an accident which harms the body, ${ }^{52}$ is that they stop breathing. ${ }^{53}$ The breath of life with which God inspired the first human being, the nishmat chayim that transformed the clay form into a nefesh chaya (Gen. 2:7), now leaves the person. The person expires-the pneuma (breath/spirit/nishmat chayim) having been relinquished, a life-less form remains. ${ }^{54}$ So dying as cessation of inspiration is how people naturally die - how they die by the hand of heaven. Approximating natural expiration, as we do with cheneq, means that we are imposing death as God imposes death, and it highlights death as the taking back of the life-force that God grants to human beings. When a court imposes cheneq, then, it is acting as a human mediator in the drama of God reclaiming, imperceptibly, the life which God has given.

This understanding of cheneq is sharpened when we look at cheneq within the system of arba mitot beit din. The four mitot, within rabbinic sources, form a system, not just a group of disparate modes of execution, in that each mita has a place in relation to the other mitot. The Bavli claims that the notion that there are four modes of execution is a tradition - arba mitot gemara gemiri leho.$^{55}$ The four mitot, according to the mishna, come in pairs: victims of seqila and of sereifa are buried in one cemetery, and victims of hereg and

Thus, the mita biydei shamayim here parallels the yumat in Lev. 20:10, where a person 'shall be caused to die' in response to a criminal act. It is possible, though, that Rabbi is simply referring to any death that the Torah mentions as occurring without apparent cause; such a death can be said to be 'at the hands of heaven', even if God is not mentioned as causing the death as in the case of Er and Onan. My use of the term 'natural death' here is not meant to favour one over the other of these interpretations of Rabbi's reference; it seems to me that, whether we understand Rabbi to be referring to special cases where God is said to impose death for a misdeed or whether we understand Rabbi to be referring to any case where a person simply dies, the idea is that mita connotes death that has no apparent physical cause - the person has simply stopped breathing. See bSan 52a, where the word vayamutu, used of Aharon's sons, is understood to suggest that their sereifa was 'like mita' - that is, it was not simply that they died, but that their manner of death was like mita, in that there was no apparent physical cause of death.

52 Or a sickness/fever which 'burns' the body from the inside; see n. 30, above.

53 Death is determined, in rabbinic sources, by cessation of breathing; see, for example, bYoma 85a. This is not to say that all deaths are seen to be caused by lack of breathing; but lack of breathing is, always, a sign of death, and, in cases where there is no apparent cause of death, expiration is the cause - or, perhaps better, the definition — of death. Note the use of vayigva to describe the deaths of the patriarchs in Gen. 25:8, 35:29, and 49:33. And see Gen. 7:21-22, where death by drowning in the floodwaters is described with the word vayigva ; note the designation of the creatures that died as 'all which had the breath of the spirit of life in its nostrils'. For the flood in relation to cheneq, see 'Crimes and Punishments, Part II', n. 29 and accompanying text.

54 See A. Kosman, 'Kissing the Dead-Transformation of a Custom' (in Hebrew), Tarbiz 65 (1996), 483-508, especially the appendix, pp. 504-508, and also n. 42, about death by a divine kiss as a taking back of the breath of life. Kosman notes Rashi's comment in bBava Batra 17a, s.v. kede'amran, contrasting death by a divine kiss with death at the hands of the Angel of Death described in bAvoda Zara 20b. See n. 30, above. A similar conception, of course, lies behind the offering of good wishes to a person who sneezes, forcibly expelling breath, and behind the phrase 'to give up the ghost', among many other examples.

55 bSan 53a-Rava makes this claim in response to the question: how can R. Yoshiya explain the law that cheneq is the default mita by saying that we must impose the most lenient mode of execution? If this is the motivating factor, R. Yoshiya ought to assume that, when the Torah does not specify a mode of execution, the court ought impose hereg, the most lenient of the known modes of execution! How do we know, asks the gemara, that cheneq exists at all? 
of cheneq in another. ${ }^{56}$ Further, there is a dispute in the mishna as to the relative severity of the two mitot in each pair: while the standard (anonymous) opinion is that seqila is more severe than sereifa and that hereg is more severe than cheneq, R. Shim on reverses the order in both pairs. ${ }^{57}$ From the perspective of either opinion, then, each mita occupies a unique spot within the total system: it is one of four mitot; it belongs to either the more or the less severe pair of mitot; and it is either the more or less severe within that pair. Working with the standard opinion, then, we can visualise the four mitot as occupying four quadrants of a complete system:

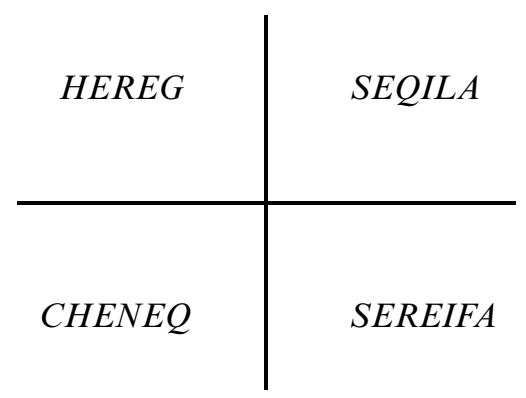

The vertical line separates the more severe pair, on the right, from the more lenient pair, on the left. This corresponds, according to the mishna, with the division that applies to burial of the executed criminal. The horizontal line divides the more severe in each pair, above, from the less severe, below. According to R. Shimon, the chart would need to be flipped along the horizontal axis.

Moving back to the vertical axis, one might also note that the mitot on the right are the ones that the Torah explicitly mandates for specific crimes, ${ }^{58}$ while the ones on the left are innovations of the rabbinic system. ${ }^{59}$ The bottom of these two left-hand mitot is reserved as the default mita for Jewish courts, while the top one is said in rabbinic sources to be the way government officials and non-Jewish courts execute criminals. ${ }^{60}$ Also, as will be discussed in Part II of this study, the two left-hand mitot correspond to the two positions in the Bavli as to the form of punishment used for all violations of noachide law. ${ }^{61}$

\footnotetext{
$56 \mathrm{mSan}$ 6:5. The Bavli (bSan 47a) explains this by saying that more-evil people and less-evil people ought not to be buried together. This leads to the obvious question: why not have four burial places? The gemara responds in the same language with which Rava explains the source of the notion that there are four mitot: 'shenei qevarot gemara gemiri lei'. Thus, according to the Bavli, both the notion that there are four mitot and the notion that these mitot are grouped in pairs are handed down in the tradition.

57 mSan 7:11

58 And which also appear as spontaneous acts of violence against those who have violated norms of the community-see above, n. 37 .

${ }^{59}$ For the judicial execution of hereg as an innovation within rabbinic sources, see above, $\mathrm{n}$. 15.

60 See mSan 7:3, tSan 9:10, ySan 7:1/24b. This will be discussed further in 'Crimes and Punishments, Part II'.

61 bSan 56a, 57b, 71b.
} 
Thus, the left side of the chart, the mitot that are introduced by the rabbis, represents the primary ways in which rabbinic texts understand execution by judicial and governmental bodies as taking place.

Once we see each mita as occupying a distinct place within the rabbinic system of capital punishments, a place that is defined in relation to the other mitot in the system, we can note other things about this framework of mitot. On the right side, there are two mitot which kill by destroying: seqila by crushing or breaking the body, and sereifa by burning the insides of the body. ${ }^{62}$ On the left, in contrast, each mita kills by removing a life-substance from the body: hereg by removing the blood, the vital force that human beings share with all creatures, and cheneq by removing the breath, the spirit of life with which God inspires human beings. ${ }^{63}$ On the top, each mita kills by imposing external, visible damage to the body, and both seqila and hereg are ways in which people kill. ${ }^{64}$ On the bottom, in contrast, death comes internally and invisibly, and both sereifa and cheneq are described as ways in which God kills.

Looking at cheneq within the system of arba mitot beit din, then, underscores the elements of cheneq that I have highlighted. Cheneq is the way God causes death when God removes that life-force by which God brings people to life. This is Rabbi's understanding of the prescription yumat-'he shall be made to die' - the person shall undergo 'death' as mediated by a human court. ${ }^{65}$

Now, we could take Rabbi simply to be making a strong semantic argument ${ }^{66}$ - given a word whose connotation in a given context is undetermined, we assign or uncover its meaning by analogy to other uses, or to the usual meaning, of the word. In all such cases, we come up against a formidable methodological question: how much weight do we give the formal reasoning versus the substantive content of an exegetical argument? ${ }^{67}$ I will work with

\footnotetext{
62 What, exactly, is being burnt in sereifa is unclear. The mishna (mSan 7:2) seems clearly to suggest a physical burning of the internal organs. The Bavli (bSan 52a), in comparing execution by sereifa to the deaths of Nadav and Avihu and Qorach's congregation, describes it as sereifat neshama veguf qayam. See the passages in the Sifra, cited above, n. 29, and see Lorberbaum, Imago Dei, p. 110. Halbertal (Interpretive Revolutions, p. 147) and Lorberbaum (p. 111) both emphasise the guf qayam element of this formulation.

63 See the conclusion of the description of cheneq in mSan 7:3-ad shenafsho yotz'a.

${ }^{64}$ For hereg as the term used for killing by a human being, see below, n. 31 .

65 See the three-way dispute in bSan 84a about the connotation of yumat in Numbers 18:7. R. Yishma'el feels that yumat (passive form) and yamut (active form) have the same connotation: death by the hand of heaven. R. Aqiva and R. Yochanan ben Nuri, on the other hand, believe that yumat connotes execution by a court. Rabbi's interpretation of yumat in Lev. 20:10 seems to mediate between these two options - the person is put to death by human hands but in a way that approximates divinely caused death.

66 See Halbertal, Interpretive Revolutions, pp. 155-156.

67 See above in relation to the Bavli's discussion of sereifa: are the cases of benei aharon and adat qorach being brought simply to expand the semantic range of the word $s-r-f$, or is the text making a point about the punishment of sereifa as simulating divinely imposed sereifa? There, though, the cases of internal burning are an intermediate, though extended, step in the argument, with the conclusion about the mode of sereifa coming from the principle of mita yafa, and thus there may be more reason to see this step as formal rather than substantive. Here, in contrast, the case of mita biydei shamayim is brought to yield the conclusion - that we should execute
} 
the assumption that Rabbi is making more than a formal argument, that he is underscoring the nature of cheneq as a human approximation of death by the hand of heaven, an understanding supported by the place of cheneq within the system of arba mitot beit din.

So, then, the question is this: if we take seriously this understanding of cheneq, how do we explain it? Why do rabbinic sources design a criminal justice system such that the standard death penalty simulates 'dying'relinquishing to God the God-given breath of life? What follows is a conjectural answer to this question, an answer that looks to a different domain than other explanations of mitot beit din with which I am familiar. I want to suggest a jurisprudential answer - an explanation of the punishment of cheneq as reflecting a particular understanding of a particular system of law and of the meaning, within that system, of violating law.

\section{Rabbinic Jurisprudence}

The rabbinic conception of sinaitic law ${ }^{68}$ is rooted in the notion of command. To follow the law is to obey God's command; to violate the law is to disobey God's command ${ }^{69}$ God's law consists of those commands articulated in the Torah. According to the rabbinic conception of the legal system, no violation of law is punishable unless it is of a prohibition that is explicitly proscribed (azhara) and the punishment for violation of which is explicitly stated (onesh) ${ }^{70}$ This conception of law as commanded and sanctionable is reflected,

in a similar way, cheneq - and this suggests that we should take the substantive content of this argument seriously. Nevertheless, the methodological question remains, both in cases of halakhic and aggadic exegesis. Often, the interpreter treads a tricky line between the temptation of reading in, on the one side, and the danger of missing the point, on the other.

${ }^{68} \mathrm{I}$ am using this term to designate the body of law that is seen in rabbinic sources as having its roots in sinaitic revelation as opposed to other bodies of law, such as noachide law, to be discussed in 'Crimes and Punishments, Part II'.

${ }^{69}$ This conception of law is known as legal positivism. For a basic introduction to positivism and to alternate conceptions of law, see Salmond on Jurisprudence, 12th edn, P. J. Fitzgerald (London, 1966), esp. 15-53. For the classic modern work on legal positivism with a review and critique of earlier versions of positivism, see H. L. A. Hart, The Concept of Law (New York, 1997). For other descriptions of the rabbinic conception of law as essentially positivist, see Y. Silman, 'Halakhic Determinations of a Nominalistic and Realistic Nature: Legal and Philosophical Considerations' (in Hebrew), Dine Israel 12 (1984-1985), 251-266, and D. Schwartz, 'Law and Truth: On Qumran-Sadducean and Rabbinic Views of Law', in The Dead Sea Scrolls: Forty Years of Research, ed. D. Dimant and U. Rappaport (Leiden and Jerusalem, 1992), 229-240; see J. Rubinstein's response to Schwartz, 'Nominalism and Realism in Qumranic and Rabbinic Law: A Reassessment', Dead Sea Discoveries 6 (1999), 157-183. For an extreme statement of this understanding of the mitzvot, see Maimonides' commentary to the passage in mChulin 7:6 concerning the prohibition of eating gid hanashe. The positivistic view of the mitzvot raises the question of the status of these laws before Sinai. How, for example, are we to understand the nature of the patriarchs' observance of the mitzvot asserted in many midrashic texts? For a discussion of the issue of the status of law before Sinai in non-rabbinic texts, see G. Anderson, 'The Status of the Torah Before Sinai', Dead Sea Discoveries 1 (1994), 1-30, and 'The Status of the Torah in the Pre-Sinaitic Period: St Paul's Epistle to the Romans', in Biblical Perspectives: Early Use and Interpretation of the Bible in Light of the Dead Sea Scrolls, ed. M. Stone and E. Chazon (Leiden, 1998), 1-13.

70 By 'explicitly' I do not mean that it is explicit in the common sense of the word-in fact, 
also, in the notion of hatra'a (warning) as elaborated in rabbinic sources. According to one opinion, the function of hatra' $a$ is simply 'to distinguish between shogeig (non-deliberate) and meizid (deliberate)', and thus hatra'a may be omitted in cases where this determination is unnecessary. ${ }^{71}$ But the standard position has hatra' $a$ as an essential element without which the violator of law cannot be brought to trial for a capital offence. The hatra' $a$ must consist of a statement of both the prohibition and the punishment; it must take place immediately before the commission of the crime; and, moreover, the violator must verbally accept the hatra' $a$ : 'I know, and I do it on that condition. ${ }^{72}$

The commandedness and sanctionableness of law, then, must be articulated within the statutory formulation of law in the Torah (azhara and onesh), and it must be re-articulated to the would-be violator of law at the moment of violation (hatra'a) ${ }^{73}$ or the act is not a crime punishable in a court of law. The violator must not just hear the hatra' $a$ and indicate that he has heard it; the violator must make it clear that he is violating the law in full acceptance of its prohibitedness and punishability. In the words of the baraita in the Bavli, he both accepts upon himself the hatra' $a$ and gives himself over to death. ${ }^{74}$ The Bavli sees the source of this latter idea in the phrase yumat hameit (literally, 'the dead shall be made to die') (Deut. 17:6). ${ }^{75}$ While the Torah says: 'By the mouth of two witnesses or three witnesses yumat hameit', the derasha puts the responsibility for the death of the violator of law squarely on the violator himself - he is put to death because he has already condemned himself to die. ${ }^{76}$ It is not, then, the court that imposes death on the criminal; the criminal

often the azhara or onesh is derived through scriptural exegesis. The point is, though, that the azhara and onesh must have a scriptural source that is seen as applying specifically to the law in question; neither the azhara nor the onesh can be derived by means of logical inference. For further discussion of this principle, see 'Crimes and Punishments, Part II'.

71 See bSan 8b, 41a, 72b, bMak 6b, 9b. Note that the term shogeig (as opposed to meizid) ordinarily can apply both to situations where the violator is not aware of the prohibition (for example, he does not know that is forbidden to write on Shabbat) and to situations where the violator is aware of the prohibition but is not aware that the situation at hand falls under that prohibition (for example, he mistakenly thinks that it is a weekday, not Shabbat). It would appear that the position that a chaveir does not need a hatra'a is focusing on this first kind of shogeig, on the assumption that a chaveir would be aware of the existence of the prohibition. Presumably, it would still be necessary to ascertain whether the chaveir knows that the situation at hand falls under the prohibition. See 'Crimes and Punishments, Part II' on hatra'a in relation to noachide law and on Maimonides' distinction between the two kinds of shogeig with respect to a noachide.

72 Mekhilta deRabbi Yishma 'el, Kaspa 20, p. 327, tSan 11:2-3, ySan 5:1/22c, bSan 72b. See M. Ish-Shalom, 'Essay on the Issue of Eidim Zomemin and the Issue of Hatra'a' (in Hebrew), part II, Beit Talmud 5 (1886), 259-261, for the idea of warning as a primary meaning of leha ${ }^{\circ} \mathrm{id}$.

73 How explicitly and in what form the prohibition must be articulated is discussed by commentators. See, for example, Tosafot on bMo'ed Qatan 2 b, s.v. mishum mai matrinan - 'he must clearly spell out the name of the prohibition' - and Rashi on bShev 20b, s.v. ve'azharatei milo tishav' $u$ vishmi lashaqer and akhalti velo akhalti - the warner must quote the biblical verse that states the prohibition.

74 bSan 40b.

75 bSan 41a. In ySan 5:1/22c, this phrase is taken as the source of the requirement that the would-be criminal be told the specific penalty for the crime he is about to commit.

76 Note that this reduces the conception of the role of the witnesses significantly. This may explain why the witnesses can do no more than report the fact of the crime in a way that allows for no interpretation of the events (see above, n. 4). While this requirement can be explained 
comes to court already 'dead' - he has relinquished his right to life, and the court simply enacts that reality-yumat hameit. ${ }^{77}$

Intentional violation of God's command is, in this view, tantamount to relinquishing life. The hatra' $a$ and its acceptance elevate the crime to nothing less than a violation of God's command and a handing oneself over to death. What is left for the court upon conviction of the criminal, then, is a minimal role: essentially, making real the process that has already transpired in theory. The court simply implements yumat - effecting the death of the violator of God's command by causing the breath of life to leave that person.

In short, what I am suggesting is that cheneq reflects this conception of law as God's command and of the violation of law as a violation of God's command that results in a relinquishing of the life that God has given. Cheneq, as we saw, is the way in which a human court approximates divinely caused death. Execution by cheneq makes the court into an agent of the death merited and incurred by the person who has chosen to violate God's command.

\section{Summary}

I began this study by presenting and challenging a hypothesis advanced in recent scholarship: that biblical forms of execution are redesigned and that cheneq is introduced based on a single principle, the goal of limiting damage to the body of the executed criminal. I went on to suggest a different understanding of cheneq suggested by rabbinic sources and to locate cheneq within the system of arba mitot beit din, a system in which each form of execution has a distinct place and can be defined in relation to the other forms of execution. Cheneq, I suggested, is the realisation by a human court of the criminal's relinquishing of the life-force that God has granted.

I went on to present a hypothesis about the meaning of cheneq as the default mode of judicial execution. I suggested that we might look to punishment as a reflection of a concept of law and, in particular, that the default mita of cheneq might reflect the rabbinic conception of the nature of the legal system for violation of which the person is punished. This led to a proposed characterisation of the rabbinic understanding of the sinaitic legal system as based in divine command. Crime is a conscious, willful violation of a divine command; punishment is knowingly accepted by the criminal, who 'gives himself over to death' when he chooses to violate God's law.

The main thesis advanced here, then, is that punishment within rabbinic

as nothing more than a device for rendering conviction impossible or, instead, as fundamentally necessary to avoid convictions based on human error (for both of these possibilities, see Blidstein, 'Capital Punishment'), perhaps it ought to be seen as a way of reducing the role of the witnesses and of the court in determining the defendant's guilt. The defendant, in fact, has rendered himself guilty and has acceded to his own sentence. The role of the witnesses is nothing more than to bring this to the attention of the court.

77 The notion that the evil-doer is already considered 'dead' appears also in aggadic statements based on this same verse (Deut. 17:6). See bBer 18b and also Devarim Rabba veZo't haBerakha, s.v. vayo'mer; Tanchuma and Tanchuma Buber veZo't haBerakha 7. This notion is juxtaposed with the legal requirement of 'giving oneself over to death' in Midrash Tannaim to Deut. 17:6 and Yalqut Shimoni, Shoftim, 909. 
sources can be seen as a reflection of rabbinic jurisprudence. This thesis will be tested in Part II of this study by looking at an alternate system of law envisioned in rabbinic sources. I will focus on noachide law-in fact, on two versions of noachide law described in the Bavli. I will consider the conception of law in each of those two versions and see whether the sanction for violation of the law in each version corresponds to that version's conception of law. In addition, I will focus on one particular law - the case of brother-sister incest - to highlight the distinction that I will draw between the conception of sinaitic law, as characterised above, and the conceptions of noachide law that I will present. Finally, I will look at an anomalous law within the sinaitic system - the law of murder - and argue that the conception of this law is exceptional within the sinaitic system, and that the exceptional nature of this law finds expression in the assignment to this crime of the rare sanction of hereg.

It should be acknowledged that the notion that the assignment of punishments within rabbinic sources reflects the nature of a given law or of a system of law is, in fact, limited when one considers the whole system of arba mitot beit din. As noted at the beginning of this article, rabbinic sources are constrained by biblical sources which mandate specific forms of execution for specific crimes. These forms of execution - seqila and sereifa - are redesigned in rabbinic sources, and they are also limited in the scope of their application: sereifa is not assigned to any crimes other than the two for which it is mandated in the Torah, ${ }^{78}$ while seqila is assigned to a few crimes in addition to the ones for which it is explicitly mandated in the Torah. ${ }^{79}$ In the redesign of these mitot, one can, in fact, discern motivating rabbinic ideas, such as the desire to minimise suffering and the preservation of human dignity (both falling under the rubric of 'beror lo mita yafa') and the increased institutionalisation of criminal punishment. ${ }^{80}$ But it is to the non-biblical mitot that one must look to discover what judicial execution would look like if designed without the constraints of the Torah's designation and description of modes of execution. Hence, the focus here on cheneq - the mode of execution designed whole-cloth by the rabbis and assigned as the default mita for violations of law for which the Torah does not specify the form of death-and the suggestion that it is here that we can look to see a reflection of the rabbinic conception of sinaitic law and its violation. ${ }^{81}$

78 See Lev. 20:14 and 21:9 and mSan 9:1.

79 See n. 38, above.

80 For a suggestion that, in the rabbinic assignment of seqila to particular crimes for which seqila is not explicitly mandated in the Torah, we might also see a reflection of the rabbinic conception of the nature of those particular crimes and of that particular punishment, see nn. 38 and 41 , above.

81 Note that only cheneq and hereg, the two non-biblical modes of judicial execution, are assigned by rabbinic sources to systems of law: cheneq to sinaitic law (as the default mita) and to Tanna deVei Menashe's version of noachide law and hereg to the Rabbis' version of noachide law and to (Jewish and non-Jewish) governmental execution (see 'Crimes and Punishments, Part II'). This is another indication that seqila and sereifa should be seen as constraints generated by biblical sources; when rabbinic sources assign modes of execution to different systems of law, their choices are limited to cheneq and hereg. See 'Crimes and Punishments, Part II', n. 30. 